\title{
Assessment of Microbial Load from the Polayamide Netting Materials kept in Soil, Water and Atmosphere
}

\author{
Sandipan Mondal ${ }^{1 *}$, Mosaraf Hossain ${ }^{1}$, Arnab Bandyopadhyay ${ }^{1}$, \\ Devika Pillai ${ }^{2}$ and B. Manojkumar ${ }^{3}$ \\ ${ }^{1}$ Fishery Engineering \& Technology, Kerala University of Fisheries and \\ Ocean Studies, Kerala, India \\ ${ }^{2}$ Department of Fish Pathology, Kerala University of Fisheries and Ocean Studies, \\ Kerala, India \\ ${ }^{3}$ Department of Pathology Payyanur Fisheries Station, Kerala, India \\ *Corresponding author
}

A B S T R A C T

\section{Keywords \\ Polyamide, \\ Monofilament, \\ Multifilament, Microbial load \\ Article Info \\ Accepted: \\ 10 August 2018 \\ Available Online: \\ 10 September 2018}

Polyamides are the most commonly used polymers for routine applications as well as in the fisheries sector for the construction of fishing gear due to its high resistancey. The accumulation of polyamide after thrown in environment or the effect of ghost fishing is a threat to environment as it causes pollution, creating an imbalance in the ecosystem, thus proving to be hazardous. As polyamide is highly resistant to the environment, the natural degradation of polyamide is too time consuming and at the same time the ways to degrade polyamide have not been successful. The main objective of the present study is to assess the microbial load of the polyamide netting materials exposed in soil, water and atmosphere using standard microbial procedures.

\section{Introduction}

The use of polyamide materials have been increased in food clothing, shelter, transportation, construction, medical, and recreation industries.

They are most widely used worldwide as they are having certain advantages like they are strong, light-weighted, durable and having the highest elastic recovery than any other polymer. However, they are disadvantageous as they are resistant to biodegradation, leading to pollution, harmful to the natural environment. Increasing environmental pollution and waste that cannot be renewed and degrade it encourages research and studies in the field of biosynthetic and biodegradation material. One of the waste that cannot be destroyed is polyamide waste, which is a type of a plastic waste.

\section{Materials and Methods}

The test material comprised samples of: (i) PA monofilament yarn of specification viz. of diameter $0.23 \mathrm{~mm}$ diameter and (ii) $\mathrm{PA}$ multifilament twine of specification, viz. 210 $\mathrm{d} \times 1 \times 2$.

Samples were kept in three environmental conditions i.e., water, atmosphere and soil. 
Sub-samples from the test material were removed for the assessment of microbial load after 8, 15, 30, 45, 60, 90 days of exposure. The test exposure was done from February, 2018 to May, 2018.

\section{Soil}

Polyamide samples were buried in soil at 20 $\mathrm{cm}$ depth sewn with vinyl-coated polypropylene $(\mathrm{PP})$ rope $2 \mathrm{~cm}$ apart on a frame. Samples were buried in the experimental tank outside the Department of Fishery Engineering \& Technology, Kerala University of Fisheries and Ocean Studies at a latitude of $9^{\circ} 54^{\prime} 44.92 " \mathrm{~N}$ and longitude of $76^{\circ} 19^{\prime} 2.67 " \mathrm{E}$.

\section{Marine condition}

Experiment was conducted by keeping the samples in a glass aquarium of the size $180 \mathrm{~cm} \times 80 \mathrm{~cm} \times 80 \mathrm{~cm}$; length, width, height having a total capacity of $1000 \mathrm{~L}$. Seawater was collected from Chellanam, Kochi (Kerala) in plastic drums. Samples were sewn into a rope made with plastic to prevent eventually forming fragments from falling apart. The rope was with non-biodegradable vinyl-coated polypropylene having a diameter of about $280 \mathrm{~mm}$.

The rope along with the nylon samples were suspended in the aquarium, the distance between the samples was approximately $5 \mathrm{~cm}$. To avoid large temperature fluctuations the tank was kept inside lab and covered with a sheet.

\section{Atmospheric condition}

The samples were exposed to atmospheric conditions on the roof top of the Department of Fisheries Engineering Kerala University of Fisheries and Ocean Studies (9 $54^{\prime} 44.92 " \mathrm{~N}$ and $76^{\circ} 19^{\prime} 2.67 " \mathrm{E}$ ) for a period of 3 months from February to May 2018. The two ends of the samples were tied to Polypropylene ropes with a $2 \mathrm{~cm}$ gap in between and taking care that there is no tension in the material and then mounted on a frame of $1 \mathrm{~m} \times 0.7 \mathrm{~m}$.

Microbial load and colony morphology was assessed after each sampling by taking Total Plate Count and visual observation. Assessment of total plate count (TPC) was done as per the standard procedure given below and colonies were serially numbered based on their morphological characters such as color, shape, transparency etc. 10 grams of exposed sample was collected using a sterile scissor and transferred into a sterile mortar.

No. of bacteria $/ \mathrm{g}=($ No. of colonies per $\mathrm{ml} \mathrm{x}$ reciprocal of dilution $\mathrm{x} 100$ ) / weight of the sample

\section{Results and Discussion}

Colony morphology and microbial load during each sampling time of each sample was observed. Microbial load of the sample during each sampling time is shown in Table 1 . In soil the microbial load after $90^{\text {th }}$ day for mono and multifilament were $2.3 \times 10^{\wedge} 5 \mathrm{cfu} / \mathrm{g}$ and $1.7 \times 10^{\wedge} 6 \mathrm{cfu} / \mathrm{g}$ respectively.

In water the loads were $2.1 \times 10^{\wedge} 7 \mathrm{cfu} / \mathrm{g}$ and $2.3 \times 10^{\wedge} 6 \mathrm{cfu} / \mathrm{g}$ respectively. In atmosphere for mono and multifilament samples upto $3^{\text {rd }}$ and 2nd sampling, there were no colonies found in petri plates. However, at the end of 90 the day microbial load on mono and multifilament were $3.3 \times 10^{\wedge} 4 \mathrm{cfu} / \mathrm{g}$ and 3.9 $\mathrm{X} 10^{\wedge} 4 \mathrm{cfu} / \mathrm{g}$.

Table 2 showed the morphological characteristics of the colonies with color, margin and shape. Among the all colonies, yellow and pale yellow color colonies were found from samples of all three environments and were most abundant. 
Table.1 Microbial load of mono and multifilament samples in different environments

\begin{tabular}{|c|c|c|c|c|c|c|}
\hline & \multicolumn{3}{|c|}{ MONOFILAMENT SAMPLES } & \multicolumn{3}{|c|}{ MULTIFILAMIENT SAMPLES } \\
\hline DAY & $\begin{array}{c}\text { SOIL } \\
(\text { CFU/g) }\end{array}$ & $\begin{array}{l}\text { WATER } \\
(\text { CFU/g) }\end{array}$ & $\begin{array}{c}\text { ATMOSPHERE } \\
(\text { CFU/g) }\end{array}$ & $\begin{array}{c}\text { SOIL } \\
(\text { CFU/g) }\end{array}$ & $\begin{array}{l}\text { WATER } \\
\text { (CFU/g) }\end{array}$ & $\begin{array}{c}\text { ATMOSPHERE } \\
(\mathrm{CFU} / \mathrm{g})\end{array}$ \\
\hline 8 & $3.1 \times 10^{\wedge} 4$ & $3.5 \times 10^{\wedge} 5$ & No colony & $4.0 \times 10^{\wedge} 4$ & $2.5 \times 10^{\wedge} 5$ & No colony \\
\hline 15 & $3.7 \times 10^{\wedge} 4$ & $1.7 \times 10^{\wedge} 6$ & No colony & $2.5 \times 10^{\wedge} 5$ & $2.8 \times 10^{\wedge} 5$ & No colony \\
\hline 30 & $4.2 \times 10^{\wedge} 4$ & $2.2 \times 10^{\wedge} 6$ & No colony & $3.0 \times 10^{\wedge} 5$ & $3.0 \times 10^{\wedge} 5$ & $3.4 \times 10^{\wedge} 4$ \\
\hline 45 & $4.6 \times 10^{\wedge} 4$ & $2.3 \times 10^{\wedge} 6$ & $2.8 \times 10^{\wedge} 4$ & $3.3 \times 10^{\wedge} 5$ & $1.6 \times 10^{\wedge} 6$ & $3.5 \times 10^{\wedge} 4$ \\
\hline 60 & $2.0 \times 10^{\wedge} 5$ & $8.7 \times 10^{\wedge} 6$ & $3.1 \times 10^{\wedge} 4$ & $1.3 \times 10^{\wedge} 6$ & $1.7 \times 10^{\wedge} 6$ & $3.6 \times 10^{\wedge} 4$ \\
\hline 90 & $2.3 \times 10^{\wedge} 5$ & $2.1 \times 10^{\wedge} 7$ & $3.3 \times 10^{\wedge} 4$ & $1.7 \times 10^{\wedge} 6$ & $2.3 \times 10^{\wedge} 6$ & $3.9 \times 10^{\wedge} 4$ \\
\hline
\end{tabular}

Table.2 Assessment of microbial load of mono and multifilament samples in difference conditions on agar medium

\begin{tabular}{|c|c|c|c|c|c|c|c|c|}
\hline \multirow{4}{*}{ SOIL } & $\begin{array}{l}\text { Colony } \\
\text { no. }\end{array}$ & 1 & 2 & 3 & 4 & 5 & 6 & 7 \\
\hline & Color & Yellow & Transparent & White & Green & $\begin{array}{l}\text { Creamish } \\
\text { white }\end{array}$ & Red & Pale yellow \\
\hline & Shape & Round & Round & Round & Irregular & Oval & Oval & Rod \\
\hline & Margin & Circular & Circular & Circular & Weavy & Circular & Circular & Cylindrical \\
\hline \multirow[t]{4}{*}{ WATER } & $\begin{array}{l}\text { Colony } \\
\text { no. }\end{array}$ & 1 & 2 & 3 & 4 & 5 & 6 & \\
\hline & Color & White & Pale yellow & $\begin{array}{c}\text { Creamish } \\
\text { white }\end{array}$ & yellow & Red & Orange & \\
\hline & Shape & Rod & Rod & Oval & Round & Round & Oval & \\
\hline & Margin & Circular & Circular & Circular & Circular & Circular & Circular & \\
\hline \multirow[t]{4}{*}{ ATMOSPHERE } & $\begin{array}{l}\text { Colony } \\
\text { no. }\end{array}$ & 1 & 2 & & & & & \\
\hline & Color & Yellow & Pale yellow & & & & & \\
\hline & Shape & Round & Irregular & & & & & \\
\hline & Margin & Circular & Weavy & & & & & \\
\hline
\end{tabular}

A gradual increase in the microbial load was observed for both samples in all three environments. At the end of the 90 days the microbial load was maximum for the samples kept in water for both mono and multifilament and minimum for the samples kept in atmosphere. Types of microbes found more in the samples kept in soil and minimum was found in the samples kept in atmosphere.

\section{Acknowledgement}

I wish to thank Director, Central Institute of Fisheries Technology, Kochi; Vice Chancellor, Kerala University of Fisheries \& Ocean Studies, Kochi for the opportunity to carry out the work. 


\section{References}

Asmita, K., Shubhamsingh, T. and Tejashree, S., 2015. Isolation of plastic degrading micro-organisms from soil samples collected at various locations in Mumbai, India. Int Res J EnvirSci, 4(3), pp.77-85.

Gouda, M.K., Swellam, A.E. and Omar, S.H., 2012. Biodegradation of synthetic polyesters (BTA and PCL) with natural flora in soil burial and pure cultures under ambient temperature. Research Journal of Environmental and Earth Sciences, 4(3), pp.325-333.

Mahdiyah, D. and Mukti, B.H., 2013. Isolation of Polyethylene Plastic
Degrading-Bacteria. Biosci. Inter, 2(3), pp.29-32.

Singh, G., Singh, A.K. and Bhatt, K., 2016. Biodegradation of polythenes by bacteria isolated from soil. Int $J$ Res Dev Pharm L Sci, 5(2), pp.2056-2062.

Skariyachan, S., Patil, A.A., Shankar, A., Manjunath, M., Bachappanavar, N. and Kiran, S., 2018. Enhanced polymer degradation of polyethylene and polypropylene by novel thermophilic consortia of Brevibacillus sps. And Aneurini bacillus sp. screened from waste management landfills and sewage treatment plants. Polymer Degradation and Stability, 149, pp.52-68.

\section{How to cite this article:}

Sandipan Mondal, Mosaraf Hossain, Arnab Bandyopadhyay, Devika Pillai and Manojkumar, B. 2018. Assessment of Microbial Load from the Polayamide Netting Materials Kept in Soil, Water and Atmosphere. Int.J.Curr.Microbiol.App.Sci. 7(09): 1437-1440. doi: https://doi.org/10.20546/ijcmas.2018.709.172 